\title{
Comparative study of fatty acid profiles in the muscular tissue (Longissimus dorsis) of bovines from Chile, Paraguay and Brazil
}

\author{
Marcela ZAMORANO ${ }^{\star *}$ (D), Gerda TOMIC ${ }^{1}$, Jose Rolando SILVA ${ }^{1}$, Fernando OSORIO ${ }^{1}$
}

\begin{abstract}
Per capita meat consumption in Chile is $89.1 \mathrm{~kg}$ per year in 2014, of which approximately $25 \mathrm{~kg}$ are beef. Some $50 \%$ of the beef consumed is imported as vacuum packaged meat from two species, Bos taurus, produced mainly in Chile, Argentina and Paraguay, and Bos indicus, which comes mainly from Brazil and Paraguay. The latter two countries account for the highest levels of beef imports in Chile. The objective of this investigation was to study and compare the fatty acid profiles of beef from Bos Taurus from Chile and Bos indicus from Paraguay and Brazil. Samples of vacuum packaged Longissimus dorsi muscle tissue were collected from private companies, two Chilean, three Paraguayan and two Brazilian. The fatty acid profiles were determined by GLC according to standardized regulations. There were differences in the fat profiles of the analyzed meats, mainly in the content of saturated and monounsaturated fatty acids. Brazilian and Paraguayan beef had similar fat compositions, with higher saturated fat content and lower monounsaturated fat content than the Chilean beef. The saturated and monounsaturated fat contents in the Chilean beef were similar. All the analyzed beef samples had a low content of trans and polyunsaturated fats.
\end{abstract}

Keywords: bovine meat; Bos taurus; Bos indicus; fatty acids profile.

Practical Application: The fatty acid profile of beef influences in its nutritional quality.

\section{Introduction}

Meat consumption in Chile is at an historic high. According to the ODEPA (Chile, 2014), per capita meat consumption was $89.1 \mathrm{Kg}, 3.5 \%$ over what was recorded for 2012 ( $87.5 \mathrm{kilos}$ ). Of this volume, $37.5 \mathrm{Kg}$ was poultry, $26.6 \mathrm{Kg}$ pork and $24.4 \mathrm{Kg}$ beef. Beef production in 2013 continued the rising trend of previous years, with a cumulative increase since 2010 of $6.4 \%$. However, despite the increase production is not meeting demand and meat imports fill the gap. Currently, of the 24.4 kilos of beef sold per capita per year, $50 \%$ is imported. Imported beef in refrigeration (vacuum packaged) comes from two species Bos taurus taurus, which is produced in Argentina and Uruguay, and Bos taurus indicus, which comes mainly from Brazil and Paraguay, the latter two countries being the major sources of imported beef to Chile (Chile, 2014).

Fat and the fatty acid composition of muscle and adipose tissue significantly affect the quality of meat, in particular its nutritional value (Wood et al., 2008) and palatability (Smith et al., 2004). The main factors determining the fatty acid content are the species and feeding. Ruminant muscle fat has high saturated fatty acid content as a result of microbial biohydrogenation in the rumen (Aurousseau et al., 2004; Jenkins et al., 2008). This fat is characterized by low levels of essential fatty acids like linoleic (C18:2w6) and linolenic acid (C18:3w6), which could be due to the reductive effect of ruminant bacteria on double bonds, producing saturation of fatty acid (Wood et al., 2008). Some authors have also suggested the saturated fatty acid content can be modified, given that one of the variables affecting this content is the diet of the animal. Manner et al. (1984) and Mitchell et al. (1991) observed that omega-3 fatty acids predominate in animals fed on diet with high forage content (grass, hay and silage, while omega- 6 predominates in animals fed on cereals and concentrates, in particular linoleic acid, with concentrations ten times as high as those of omega-3. Elmore et al. (2004) observed the effect of diet on all fatty acids except for conjugated linoleic acid (CLA), with a higher polyunsaturated/saturated fatty acid ratio in animals fed on concentrates and a higher percentage of total lipids in the animals fed on silage. In terms of species, Huerta-Leidenz et al. (1993) documented significant differences in fatty acid composition between Bos Taurus and Bos indicus, the former having a higher content of saturated fatty acids and lower mono and polyunsaturated fat content.

It is known that saturated fatty acids (SFA) present in animal fat significantly raise the levels of serum cholesterol and of cholesterol in low-density lipoproteins, which are atherogenic. The United Nations Food and Agriculture Organization (FAO) and the World Health Organization (WHO) (1994) recommend SFA intake not exceed $10 \%$ of total energy and linoleic acid intake of 4 to $10 \%$. Given that the recommended total fat intake is $30 \%$ of total energy, monounsaturated fatty acids (MUFA) should provide the difference between polyunsaturated fatty acids (PUFA) and SFA in a 1:1:1 ratio. As well, the ratio of the PUFAs omega- 6 and omega- 3 should be in the range of 5:1 to 10:1 as a maximum (Food and Agriculture Organization of the United Nations, 1994). 
Based on the above, the objective of the present work was to determine and compare the fatty acid profiles of beef of the species Bos Taurus from Chile and Bos indicus from Paraguay and Brazil, which are sold in Chile.

\section{Materials and methods}

\subsection{Materials}

The meat samples, taken from the long dorsal muscle (Longissimus dorsi) and vacuum packaged with 30 days of storage, were obtained from five meat-importing companies, three Paraguayan and two Brazilian, and from two meatpackers in Chile. Five samplings were made, in each of which two samples of meat were obtained. The samples were taken in their original vacuum packaging to the Food Analysis Laboratory of the Technology Faculty of the Universidad de Santiago where the name, origin, date and weight were registered and they were assigned identification numbers. In the laboratory the samples were homogenized in a food processor (Moulinex, model D56) and then divided into two portions that were placed in hermetic bags and refrigerated at 3 to $5{ }^{\circ} \mathrm{C}$. One of the sample pairs was kept as a counter sample and the other was used for extracting fat and subsequent analysis in triplicate of the fatty acid profile.

\subsection{Total lipid extraction and fatty acid composition}

A mixture of chloroform and methanol (2:1 v/v) was used to extract fat in accordance with Bligh \& Dyer (1959), Association of Official Analytical Chemist (2016).

Fatty acid composition was determined by liquid-gas chromatography following preparation of methyl esters according to ISO 5509 standards, using $\mathrm{NaOH} 0.5 \mathrm{M}$ for saponification, isooctane as the solvent and boron trifluoride-methane as the esterifying agent (Spanish Association for Standardization and Certification, 2017). A Perkin Elmer gas chromatograph was used with a BPX 70 column (SGE) $60 \mathrm{~m}$ long and $0.25 \mathrm{~mm}$ in internal diameter, with an ionization flame detector and employing helium as the carrier gas. The operating parameters were as follows: injector temperature $250^{\circ} \mathrm{C}$ in the split mode, detector temperature $250{ }^{\circ} \mathrm{C}$, column temperature $150{ }^{\circ} \mathrm{C}$ for 5 minutes and then $198^{\circ} \mathrm{C}$ for 20 minutes, with an increase of $5^{\circ} \mathrm{C}$ per minute, followed by a second temperature ramp of $4{ }^{\circ} \mathrm{C}$ per minute until reaching $220^{\circ} \mathrm{C}$ for a final time of 10 minutes, a carrier gas flow of $1 \mathrm{ml}$ per minute and an injection volume of 0.5 ul. A fatty acid standard mixture (Nu-Check Prep, Inc.) was used to identify the fatty acids by comparing retention times of the standard mix to those of the samples. This yielded a fatty acid profile expressed percentages of methyl esters. An ANOVA $(\mathrm{P}<0.05)$ was applied to assess significant differences among the samples, using Excel $^{\circledR} 2010$.

\section{Results}

Tables 1, 2 and 3 show the fatty acid profiles of meat from Brazil, Paraguay and Chile, respectively. In the statistical analysis only some fatty acids presented significant differences among meat samples from the same source. Significant differences $(\mathrm{P}<0.05)$ were found in Brazilian meat in the content of polyunsaturated
Table 1. Fat content and fatty acid profile in bovine muscle tissue of the species Bos indicus from two Brazilian companies, expressed as percentages of methyl esters.

\begin{tabular}{lcc}
\hline & Brazilian 1 & Brazilian 2 \\
\hline C14:0 & $6.74 \pm 0.05^{\mathrm{a}}$ & $5.21 \pm 0.03^{\mathrm{a}}$ \\
C14:1 & $1.16 \pm 0.01^{\mathrm{a}}$ & $0.79 \pm 0.03^{\mathrm{b}}$ \\
C16:0 & $27.1 \pm 0.6^{\mathrm{a}}$ & $27.8 \pm 0.5^{\mathrm{a}}$ \\
C16:1 $\omega 9$ & $3.1 \pm 0.2^{\mathrm{a}}$ & $3.4 \pm 0.5^{\mathrm{a}}$ \\
C17:0 & $1.2 \pm 0.1^{\mathrm{a}}$ & $1.0 \pm 0.2^{\mathrm{a}}$ \\
C18:0 & $19.3 \pm 0.9^{\mathrm{a}}$ & $19.1 \pm 0.9^{\mathrm{a}}$ \\
C18:1 $\omega 9$ & $36.8 \pm 0.2^{\mathrm{a}}$ & $37.3 \pm 0.2^{\mathrm{a}}$ \\
C 18:1 trans total & $1.00 \pm 0.02^{\mathrm{a}}$ & $0.98 \pm 0.02^{\mathrm{a}}$ \\
C18:2 $\omega 6$ & $2.2 \pm 0.3^{\mathrm{a}}$ & $2.9 \pm 0.3^{\mathrm{a}}$ \\
C18:2 trans total & $0.32 \pm 0.04^{\mathrm{a}}$ & $0.21 \pm 0.05^{\mathrm{a}}$ \\
C18:3 $\omega 3$ & $0.19 \pm 0.05^{\mathrm{a}}$ & $0.39 \pm 0.07^{\mathrm{b}}$ \\
C20:0 & $0.5 \pm 0.2^{\mathrm{a}}$ & $0.5 \pm 0.2^{\mathrm{a}}$ \\
C20:1 & $0.10 \pm 0.01^{\mathrm{a}}$ & $0.12 \pm 0.04^{\mathrm{a}}$ \\
C20:4 & $0.29 \pm 0.01^{\mathrm{a}}$ & $0.3 \pm 0.04^{\mathrm{a}}$ \\
AGS (saturated fatty acids) & $\mathbf{5 4 . 9} \pm \mathbf{0 . 9}^{\mathrm{a}}$ & $\mathbf{5 4} \pm \mathbf{1}^{\mathrm{a}}$ \\
AGM (monounsaturated fatty acids) & $\mathbf{4 1 . 2} \pm \mathbf{0 . 2}^{\mathrm{a}}$ & $\mathbf{4 1 . 6} \pm \mathbf{0 . 5}$ \\
AGPI (polyunsaturated fatty acids) & $\mathbf{2 . 7} \pm \mathbf{0 . 3}^{\mathrm{a}}$ & $\mathbf{3 . 3} \pm \mathbf{0 . 3}$ \\
AGT (trans fatty acids) & $\mathbf{1 . 3} \pm \mathbf{0 . 1}^{\mathrm{a}}$ & $\mathbf{1 . 2} \pm \mathbf{0 . 1}$ \\
AGPI/AGS & $\mathbf{0 . 0 4 9}$ & $\mathbf{0 . 0 6 2}$ \\
$\omega 6 / \omega 3$ & $\mathbf{1 1 . 6 1}$ & $\mathbf{7 . 5 1}$ \\
\hline V & &
\end{tabular}

Values are the average of $n \pm$ D.S, $n=5$ compound sample $=2$, analysis in triplicate; Averages in the same row without the same letters are significantly different $(\mathrm{P}<0.05)$

fatty acids (PUFA). Something similar was observed with the Paraguayan meat, where there were no significant differences $(\mathrm{P}<0.05)$ in two samples of PUFA content, and only one of sample had a significantly higher different content $(\mathrm{P}<0.05)$. No significant differences $(\mathrm{P}<0.05)$ in the fatty acid content of the two analyzed samples of Chilean meat.

In terms of the types of fatty acids in the meats, the Brazilian and Paraguayan meats had high levels of oleic (C18:1w9) and palmitic acids (C16:0), representing around $37 \%$ and $27 \%$, respectively. On the other hand, linoleic acid (C18:2w6) content was low (3\%) linolenic acid (C18:3w3) content was even lower (around $0.3 \%$ ). Trans fatty acids (TFA) were also found in both types of meat, including elaidic acid (C18:1t) In contrast, the Chilean meat had a high oleic acid content (43\%) and consequently a lower content of palmitic acid (around 20\%). The linoleic acid content in the Chilean meat (around 1.9\%) was somewhat lower than that of the Brazilian and Paraguayan meats, while the linolenic acid was higher in the Chilean meat (up to $1 \%$ ).

Table 4 presents the total fat and saturated (SFA), monounsaturated (MUFA), polyunsaturated (PUFA) and trans fatty acid (TFA) content of the analyzed meat samples.

There were no significant differences $(P<0.05)$ in the total contents of the Paraguayan and Brazilian samples, which were close to $5.4 \mathrm{~g} / 100 \mathrm{~g}$, while the Chilean meat samples had significantly lower levels $(\mathrm{P}<0.05)$ of $4.5 \mathrm{~g} / 100 \mathrm{~g}$ on average. This implies the same situation with SFA and TFA content, which in the Paraguayan and Brazilian meat were $3.0 \mathrm{~g} / 100 \mathrm{~g}$ and $0.06 \mathrm{~g} / 100 \mathrm{~g}$ respectively, while in the Chilean meat the SFA 
Table 2. Fat content and fatty acid profile in bovine muscle tissue of the species Bos indicus from three Paraguayan companies, expressed as percentages of methyl esters.

\begin{tabular}{|c|c|c|c|}
\hline & Paraguayan 1 & Paraguayan 2 & Paraguayan 3 \\
\hline C $14: 0$ & $6.2 \pm 0.8^{\mathrm{a}}$ & $5.8 \pm 0.3^{\mathrm{b}}$ & $6.2 \pm 0.2^{\mathrm{a}}$ \\
\hline C $14: 1$ & $0.8 \pm 0.3^{\mathrm{a}}$ & $0.8 \pm 0.4^{\mathrm{a}}$ & $1.1 \pm 0.5^{\mathrm{b}}$ \\
\hline C 16:0 & $26 \pm 2^{\mathrm{a}}$ & $27.5 \pm 0.2^{\mathrm{a}}$ & $27.7 \pm 0.4^{\mathrm{a}}$ \\
\hline C 16:1 w 9 & $4 \pm 1^{\mathrm{a}}$ & $2.9 \pm 0.6^{\mathrm{b}}$ & $2.8 \pm 0.3^{\mathrm{b}}$ \\
\hline C 17:0 & $1.2 \pm 0.3^{\mathrm{a}}$ & $1.4 \pm 0.3^{\mathrm{a}}$ & $1.44 \pm 0.05^{\mathrm{a}}$ \\
\hline C 18:0 & $19 \pm 3^{\mathrm{a}}$ & $20.1 \pm 0.5^{\mathrm{a}}$ & $19.7 \pm 0.5^{\mathrm{a}}$ \\
\hline C 18:1w9 & $35 \pm 1^{\mathrm{a}}$ & $36.8 \pm 0.9^{\mathrm{a}}$ & $36.4 \pm 0.6^{\mathrm{a}}$ \\
\hline C 18:1 trans total & $0.9 \pm 0.1^{\mathrm{a}}$ & $0.9 \pm 0.1^{\mathrm{a}}$ & $0.96 \pm 0.08^{\mathrm{a}}$ \\
\hline C 18:2w6 & $2.7 \pm 0.3^{\mathrm{a}}$ & $2.2 \pm 0.3^{\mathrm{b}}$ & $1.7 \pm 0.4^{\mathrm{b}}$ \\
\hline $\mathrm{C} 18: 2$ trans total & $0.8 \pm 0.2^{\mathrm{a}}$ & $0.6 \pm 0.1^{\mathrm{a}}$ & $0.4 \pm 0.1^{\mathrm{b}}$ \\
\hline C $18: 3 w 3$ & $0.18 \pm 0.03^{\mathrm{a}}$ & $0.19 \pm 0.03^{\mathrm{a}}$ & $0.3 \pm 0.1^{\mathrm{a}}$ \\
\hline 20:0 & $0.4 \pm 0.2^{\mathrm{a}}$ & $0.4 \pm 0.1^{\mathrm{a}}$ & $0.9 \pm 0.5^{\mathrm{a}}$ \\
\hline 20:01 & $0.27 \pm 0.07^{\mathrm{a}}$ & $0.23 \pm 0.06^{\mathrm{a}}$ & $0.31 \pm 0.05^{\mathrm{a}}$ \\
\hline $20: 4 w 6$ & $0.27 \pm 0.04^{\mathrm{a}}$ & $0.18 \pm 0.03^{\mathrm{a}}$ & $0.17 \pm 0.03^{\mathrm{a}}$ \\
\hline AGS (saturated fatty acids) & $54 \pm 4^{\mathrm{a}}$ & $55.3 \pm 0.7^{\mathrm{a}}$ & $55.9 \pm 0.7^{\mathrm{a}}$ \\
\hline AGM (monounsaturated fatty acids) & $41 \pm 2^{\mathrm{a}}$ & $40 \pm 1^{\mathrm{a}}$ & $40.6 \pm 0.8^{\mathrm{a}}$ \\
\hline AGPI (polyunsaturated fatty acids) & $3.1 \pm 0.3^{\mathrm{a}}$ & $2.5 \pm 0.3^{b}$ & $2.2 \pm 0.4^{\mathrm{b}}$ \\
\hline AGT (trans fatty acids) & $1.7 \pm 0.2^{\mathrm{a}}$ & $1.5 \pm 0.2^{\mathrm{a}}$ & $1.3 \pm 0.2^{\mathrm{a}}$ \\
\hline AGPI/AGS & 0.057 & 0.045 & 0.038 \\
\hline$\omega 6 / \omega 3$ & 14.30 & 11.33 & 6.83 \\
\hline
\end{tabular}

Values are the average of $\mathrm{n} \pm$ D.S, $\mathrm{n}=5$ compound sample $=2$, analysis in triplicate; Averages in the same row without the same letters are significantly different $(\mathrm{P}<0.05)$.

Table 3. Fat content and fatty acid profile in bovine muscle tissue of the species Bos taurus from two Chilean companies, expressed as percentages of methyl esters.

\begin{tabular}{lcc}
\hline & Chilean 1 & Chilean 2 \\
\hline C14:0 & $2.4 \pm 0.2^{\mathrm{a}}$ & $3.2 \pm 0.2^{\mathrm{b}}$ \\
C14:1 & $0.6 \pm 0.1^{\mathrm{a}}$ & $0.62 \pm 0.04^{\mathrm{a}}$ \\
C16:0 & $21 \pm 1^{\mathrm{a}}$ & $20 \pm 1^{\mathrm{a}}$ \\
C16:1 $\omega 9$ & $3.2 \pm 0.8^{\mathrm{a}}$ & $3.6 \pm 0.9^{\mathrm{a}}$ \\
C17:0 & $0.98 \pm 0.08^{\mathrm{a}}$ & $1.05 \pm 0.04^{\mathrm{a}}$ \\
C18:0 & $21.9 \pm 0.8^{\mathrm{a}}$ & $22 \pm 1^{\mathrm{a}}$ \\
C18:1 $\omega 9$ & $44 \pm 1^{\mathrm{a}}$ & $44 \pm 3^{\mathrm{a}}$ \\
C 18:1 trans total & $1.9 \pm 0.1^{\mathrm{a}}$ & $2 \pm 1^{\mathrm{a}}$ \\
C18:2 $\omega 6$ & $1.3 \pm 0.4^{\mathrm{a}}$ & $1.9 \pm 0.2^{\mathrm{a}}$ \\
C18:2 trans total & $0.54 \pm 0.04^{\mathrm{a}}$ & $0.47 \pm 0.02^{\mathrm{a}}$ \\
C18:3 $\omega 3$ & $1.02 \pm 0.07^{\mathrm{a}}$ & $1.0 \pm 0.1^{\mathrm{a}}$ \\
C20:0 & $0.24 \pm 0.05^{\mathrm{a}}$ & $0.19 \pm 0.04^{\mathrm{a}}$ \\
C20:1 & $0.14 \pm 0.01^{\mathrm{a}}$ & $0.17 \pm 0.08^{\mathrm{a}}$ \\
C20: & $0.14 \pm 0.01^{\mathrm{a}}$ & $0.20 \pm 0.01^{\mathrm{a}}$ \\
AGS (saturated fatty acids) & $\mathbf{4 7} \pm \mathbf{1}^{\mathrm{a}}$ & $\mathbf{4 6} \pm \mathbf{2}^{\mathrm{a}}$ \\
AGM (monounsaturated fatty acids) & $\mathbf{4 8} \pm \mathbf{1}^{\mathrm{a}}$ & $\mathbf{4 8} \pm \mathbf{3}^{\mathrm{a}}$ \\
AGPI (polyunsaturated fatty acids) & $\mathbf{2 . 4} \pm \mathbf{0 . 4 ^ { \mathrm { a } }}$ & $\mathbf{2 . 9} \pm \mathbf{0 . 1}$ \\
AGT (trans fatty acids) & $\mathbf{2 . 4} \pm \mathbf{0 . 2 ^ { \mathrm { a } }}$ & $\mathbf{2} \pm \mathbf{1}^{\mathrm{a}}$ \\
AGPI/AGS & $\mathbf{0 . 0 5 0}$ & $\mathbf{0 . 0 6 2}$ \\
$\omega 6 / \omega 3$ & $\mathbf{1 . 3 0}$ & $\mathbf{1 . 9 1}$ \\
\hline
\end{tabular}

Values are the average of $n \pm S D, n=5$ compound sample $=2$, analysis in triplicate; Averages in the same row without the same letters are significantly different $(\mathrm{P}<0.05)$

and TFA contents were $2.1 \mathrm{~g} / 100 \mathrm{~g}$ and $0.12 \mathrm{~g} / 100 \mathrm{~g}$, respectively. However, no significant differences $(\mathrm{P}<0.05)$ were found among the Paraguayan, Brazilian and Chilean meat samples in MUFA and PUFA content.

\section{Discussions}

The results of this study confirm that there are differences in the fatty acid content in meats from animals of different species, confirming what was reported by Huerta-Leidenz et al. (1993), who also indicated that there are other factors, such as feed, sex and age, that can alter total fat content and the content of particular fatty acids. Thus, the fat profile of meat from Brazilian and Paraguayan animals showed content of over 50\% of SFA and low levels of PUFA, corroborated by the low PUFA/SFA ratio. In terms of the types of PUFA, high levels of the omega- 6 family were found, corroborated by the $\omega 6 / \omega \mathrm{w} 3$, indicating that this type of mean is of regular nutritional value. In contrast, the fat in the Chilean meat had lower levels of SFA, close to $46 \%$, and higher levels of MUFA, around the percentage as SFA. However, it had a higher TFA content than the Paraguayan and Brazilian meat samples, close to $2.5 \%$. It has been argued that MUFA reduces the risk of coronary disease and some cancers (Efrén et al., 2007), because of which this a higher content of these fatty acids improves the perception of consuming such meats. The Chilean meat also had a higher content of stearic

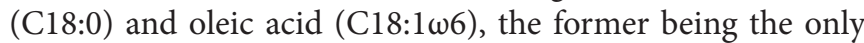
acid that has a neutral effect on blood cholesterol levels and the latter being apparently beneficial in reducing blood cholesterol and total cholesterol in low density lipoproteins in humans (Grundy, 1986). The Chilean beef presents a significantly lower $\omega 6 / \omega w 3$ ratio than the Paraguayan and Brazilian beef, which indicates greater beneficial content of linolenic acid (C18:3w3), undoubtedly as a result of the type of animal feed.

In terms of the fat content of the analyzed meats, the Paraguayan and Brazilian meats had a higher of fat, with average values of $5.3 \mathrm{~g} / 100 \mathrm{~g}$, while the Chilean meat had an average fat content 
Table 4. Total fat, saturated fat, monounsaturated fat, polyunsaturated fat content in bovine muscle tissue (Longissimus dorsi) of the species Bos indicus from Paraguay and Braz and the species Bos taurus from Chile.

\begin{tabular}{cccccccc}
\hline & Braz. 1 & Braz. 2 & Parag. 1 & Parag. 2 & Parag. 3 & Chile 1 & Chile 2 \\
\hline g Fat /100 g & $5.2 \pm 0.3^{\mathrm{a}}$ & $5.4 \pm 0.4^{\mathrm{a}}$ & $5.6 \pm 0.2^{\mathrm{a}}$ & $5.6 \pm 0.4^{\mathrm{a}}$ & $5.5 \pm 0.7^{\mathrm{a}}$ & $4.7 \pm 0.4^{\mathrm{b}}$ & $4.4 \pm 0.5^{\mathrm{b}}$ \\
g AGS/100g & $2.85^{\mathrm{a}}$ & $2.89^{\mathrm{a}}$ & $3.03^{\mathrm{a}}$ & $3.09^{\mathrm{a}}$ & $3.08^{\mathrm{a}}$ & $2.22^{\mathrm{b}}$ & $2.03^{\mathrm{b}}$ \\
g AGM /100 g & $2.15^{\mathrm{a}}$ & $2.29^{\mathrm{a}}$ & $2.30^{\mathrm{a}}$ & $2.28^{\mathrm{a}}$ & $2.23^{\mathrm{a}}$ & $2.25^{\mathrm{a}}$ & $2.12^{\mathrm{a}}$ \\
g AGPI /100 g & $0.14^{\mathrm{a}}$ & $0.18^{\mathrm{a}}$ & $0.18^{\mathrm{a}}$ & $0.14^{\mathrm{a}}$ & $0.12^{\mathrm{a}}$ & $0.11^{\mathrm{a}}$ & $0.12^{\mathrm{a}}$ \\
g AGT /100 g & $0.06^{\mathrm{a}}$ & $0.04^{\mathrm{a}}$ & $0.09^{\mathrm{a}}$ & $0.09^{\mathrm{a}}$ & $0.07^{\mathrm{a}}$ & $0.12^{\mathrm{b}}$ & $0.13^{\mathrm{b}}$ \\
\hline
\end{tabular}

Average values of $\mathrm{n} \pm \mathrm{SD}, \mathrm{n}=5$ compound sample $=2$; Averages in the same row without the same letters are significantly different $(\mathrm{P}<0.05)$.

of $4.5 \mathrm{~g} / 100 \mathrm{~g}$. In terms of the content of saturated, which is a recognized factor in increased blood cholesterol and low-density lipoprotein (LDL) levels, the Chilean meat lower levels than the Brazilian and Paraguayan meat, with a content of $2.1 \mathrm{~g} / 100 \mathrm{~g}$. This, together with the content of monounsaturated fat in the Chilean meat changes the negative perception of consuming beef and even encourages its consumption.

\section{Conclusions}

The results of the present research demonstrate that there are significant differences in the fat composition of beef sold in Chile, from Brazil, Paraguay and Chile in terms of saturated and monounsaturated fat content with significant differences in fat content. Brazilian and Paraguayan beef have similar fat content, which was expected given that they come from the same species, Bos indicus, with higher saturated fat content and lower monounsaturated content. In contrast, the Chilean beef from the species Bos taurus has similar levels of saturated and monounsaturated fat. All the analyzed meats had low trans and polyunsaturated fat content, which is characteristic of the fat of ruminants.

\section{Acknowledgements}

The authors are grateful for funding from DICYT of the Vice-Rector of Research and Development (VRIDEI) of the Universidad de Santiago de Chile.

\section{References}

Association of Official Analytical Chemist - AOAC. (2016). Official Methods of Analysis of AOAC International (20th ed.). Washington: AOAC.

Aurousseau, B., Bauchart, D., Calichon, E., Micol, D., \& Priolo, A. (2004). Effect of grass or concentrate feeding systems and rate of growth on triglyceride and phospholipids and their fatty acids in the M.Longissimus Thoracics of lambs. Meat Science, 66(3), 531-541. http://dx.doi.org/10.1016/S0309-1740(03)00156-6. PMid:22060862.

Bligh, E. G., \& Dyer, W. J. (1959). A rapid method of total lipid extraction and purification. Canadian Journal of Biochemistry and Physiology, 37(8), 911-917. http://dx.doi.org/10.1139/o59-099. PMid:13671378.

Chile. Ministerio de Agricultura. Oficina de Estudios y Políticas Agrarias - ODEPA. (2014). Tendencias de producción, precios y comercio exterior (Boletín de carne bovina). Chile: Ministerio de Agricultura.

Efrén, R., Abadía, B., Arreaza, L., Ballesteros, H., \& Muñoz, C. (2007). Factores asociados con la calidad de la carne. II parte: perfil de ácidos grasos de la carne bovina en 40 empresas ganaderas de la
Región Caribe y el Magdalena Medio. Corpoica Ciencia y Tecnología Agropecuaria, (2), 66-73.

Elmore, J., Warren, H., Mottram, D., Scollan, N., Enser, M., Richardson, R., \& Wood, J. (2004). A comparison of the aroma volatiles and fatty acid compositions of grilled beef muscle from Aberdeen Angus and Holstein-Friesian steers fed diets bases on silage or concentrates. Meat Science, 68(1), 27-33. http://dx.doi.org/10.1016/j.meatsci.2004.01.010. PMid:22062004.

Food and Agriculture Organization of the United Nations - FAO; World Health Organization - WHO. (1994). Fats and oils in human nutrition (Report of a Joint Expert Consultation). Rome: FAO.

Grundy, S. M. (1986). Comparison of monounsaturated fatty acids and carbohydrates for lowering cholesterol. The New England Journal of Medicine, 314(12), 745-748. http://dx.doi.org/10.1056/ NEJM198603203141204. PMid:3951504.

Huerta-Leidenz, N. O., Cross, H. R., Savell, J. W., Lunt, D. K., Baker, J. F., Pelton, L. S., \& Smith, S. B. (1993). Comparison of the fatty acid composition of subcutaneous adipose tissue from mature brahman and hereford cows. Journal of Animal Science, 71(3), 625-630. http:// dx.doi.org/10.2527/1993.713625x. PMid:8463149.

Jenkins, T., Wallace, R., Moate, P., \& Mosley, E. (2008). Board-invited review: Recent advances in biohydrogenation of unsaturated fatty acid within the rumen microbial ecosystem. Journal of Animal Science, 86(2), 397-412. http://dx.doi.org/10.2527/jas.2007-0588. PMid:18042812.

Manner, W., Maxwell, R. J., \& Williams, J. E. (1984). Effects of dietary regimen and tissue site on bovine fatty acid profiles. Journal of Animal Science, 59(1), 109-121. http://dx.doi.org/10.2527/jas1984.591109x.

Mitchell, G. E., Reed, A. W., \& Rogers, S. A. (1991). Influence of feeding regimen on the sensory qualities and fatty acid contents of beef steaks. Journal of Food Science, 56(4), 1102-1103. http://dx.doi. org/10.1111/j.1365-2621.1991.tb14652.x.

Smith, S., Smith, D., \& Lunt, D. (2004). Chemical and physical characteristics of meat: adipose tissue. In Jensen W, Devine C, Deichmann M, editors. Encyclopedia of meat sciences (pp. 225-238). Oxford: Elsevier Science; 2004. http://dx.doi.org/10.1016/B0-12464970-X/00120-3.

Spanish Association for Standardization and Certification - AENOR. (2017). UNE-EN ISO 12966-2:2017: animal and vegetable fats and oils - Gas chromatography of fatty acid methyl esters - Part 2: Preparation of methyl esters of fatty acids (ISO 12966-2:2017). Madrid: AENOR.

Wood, J. D., Enser, M., Fisher, A. V., Nute, G. R., Sheard, P. R., Richardson, R. I., Hughes, S. I., \& Whittington, F. M. (2008). Fat deposition, fatty acid composition and meat quality: a review. Meat Science, 78(4), 343-358. http://dx.doi.org/10.1016/j.meatsci.2007.07.019. PMid:22062452. 